DOI https://doi.org/10.30525/978-9934-588-81-5-2.45

\title{
ЧАСТОТА ВИНИКНЕННЯ ЗАПАЛЬНОЇ ПАТОЛОГІЇ ТКАНИН ПАРОДОНТА У ВАГІТНИХ
}

\author{
Смельянов Д. В. \\ кандидат медичних наук, \\ доцент кафедри хірургічних хвороб, оперативної хірургії \\ та топографічної анатомії \\ Харківський національний університет імені В. Н. Каразіна \\ Мухіна Ю. В. \\ асистент кафедри хірургічних хвороб, оперативної хірургії \\ та топографічної анатомії \\ Харківський національний університет імені В. Н. Каразіна

\section{Скрипка К. I.} \\ асистент кафедри хірургічних хвороб, оперативної хірургії \\ та топографічної анатоміі \\ Харківський національний університет імені В. Н. Каразіна \\ м. Харків, Україна
}

Попередження патології вагітності є одним з важливих профілактичних заходів в сучасній системі охорони здоров'я [1, с. 257]. Одним 3 провокуючих факторів розвитку ускладнень вагітності вважають наявність вогнища хроніосепсісу та запалення, яке являє собою зону утворення та подальшого потрапляння до кровоносного русла таких проза-

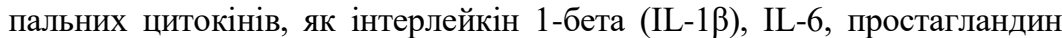
E2 та фактор некрозу пухлини-альфа (TNF- $\alpha$ ), що може мати системний вплив на організм [2, с. 54].

Запальна патологія тканин пародонта, за науковими даними, є одним з таких вогнищ і являє небезпеку для нормального протікання періоду вагітності [3, с. 1734].

Особливу зацікавленість представляє той факт, що на початку вагітності, за рахунок гормонального впливу, в інтактному пародонті відбуваються зміни, що знижують його реактивність до пародонтопатогенної мікрофлори та підвищують судинну проникність [4]. Відсутність регулярного домашнього догляду за порожниною рота, а також недотримання кратності візитів до лікаря-стоматолога 3 метою проведення профілактичних заходів для тканин пародонта вагітної, сприяє виникненню вогнища запалення та гематогенного транспортування генетичного матеріалу пародонтопатогенів і прозапальних цитокінів в плацен- 
ту, плодову і амніотичну оболонки з подальшим провокуванням передчасних пологів або народження дитини з низькою вагою [5, с. 123].

Мета дослідження. Вивчення частоти виникнення запальної патології тканин пародонта у вагітних.

Матеріали та методи. У дослідженні приймали участь 52 вагітні жінки, віком 22-36 років. Терміни вагітності коливались від 14 до 35 тижнів. Пародонтологічне обстеження проводилось за допомогою Periodontal screening and recording test (PSR-тест) [6, с. 8]. Оцінювалися скарги, наявність кровоточивості ясен та мінералізованих зубних відкладень, глибина зондування зубоясеневої борозни, наявність рецесії ясен, рухомість зубів, залучення у запальний процес фуркацій.

Результати обстеження та обговорення. Найбільшу стурбованість у 42 жінок викликала кровоточивість ясен при чищенні зубів та прийомі твердої їжі. Слід додати, що самочинна кровоточивість не турбувала вагітних в жодному випадку. В процесі об'єктивного огляду було виявлено, що запальна патологія тканин пародонта була характерна для 49 обстежених (94,2\%), причому найбільш розповсюдженою нозологічною формою був хронічний генералізований катаральний гінгівіт $(84,6 \%)$. Хронічний пародонтит був діагностований у 5 обстежених $(9,6 \%)$ - 3 них у 3 -х жінок був виявлений легкий ступінь, а у 2 -х - середній ступінь важкості захворювання. Лише у 3 -х осіб (5,7\%), з усієї групи обстежених, не було зареєстровано запального процесу в пародонті.

Характерним виявився той факт, що найбільш виражені суб'єктивні та об'єктивні зміни у яснах були притаманні жінкам з другої половини II триместру до середини III триместру (18 - 30 тижні), причому хронічний пародонтит був діагностований на III триместрі вагітності.

Враховуючи те, що хронічний катаральний гінгівіт був розповсюдженою патологією, яка повністю зворотна за рахунок лише регулярних професійних заходів гігієни, без застосування хірургічного втручання, корегування домашньої гігієни порожнини рота, а також і те, що II триместр вважається найбільш сприятливим для проведення стоматологічних маніпуляцій, то це дозволяє попередити розвиток запальних захворювань пародонта у вагітних, особливо перехід до пародонтита, неінвазивними методами, не завдаючи шкоди вагітності.

Висновки. Запальна патологія тканин пародонта у вагітних, за нашими даними, мала високу частоту виникнення та становила 94,2\%, 3 якої найбільш розповсюдженим був хронічний катаральний гінгівіт $(84,6 \%)$

Хронічний катаральний гінгівіт $є$ повністю зворотним процесом за рахунок простих методів стоматологічної профілактики, особливо у II триместрі вагітності. 
Лікарі-стоматологи мають активно спостерігати за здоров'ям та домашнім доглядом за порожниною рота у жінок на етапі планування вагітності та протягом всього періоду гестації.

\title{
Література:
}

1. Laine M.A. Effect of pregnancy on periodontal and dental health. Acta Odontol Scand. 2002. № 5(60). P. 257-264. doi:10.1080/00016350260248210.

2. Usin M. M., Tabares S. M., Parodi R. J., Sembaj A. Periodontal conditions during the pregnancy associated with periodontal pathogens. J. Investig. Clin. Dent. 2013. № 4. P. 54-59.

3. Anwar Saeed Al-Habib. et al. Changes in Periodontal Health during Various Stages of Pregnancy; An Observational Study. EC Dental Science. 2019. № 8 (18). P. 1734-1737.

4. Massoni R.S.d.S., Aranha A.M.F., Matos F.Z. et al. Correlation of periodontal and microbiological evaluations, with serum levels of estradiol and progesterone, during different trimesters of gestation. Sci Rep. 2019. № 9. P. 11762. https://doi.org/10.1038/s41598-019-48288-w

5. Seraphim A.P.C.G., Chiba F.Y., Pereira R.F., Mattera MS.L.C., Moimaz S.A.S., Sumida D.H. Relationship among periodontal disease, insulin resistance, salivary cortisol and stress levels during pregnancy. Braz Dent J. 2016. № 2(27). P. 123-127.

6. Primal K.S, Esther S.R, Boehm T.K. Periodontal Screening and Recording (PSR) Index Scores Predict Periodontal Diagnosis. J Dent App. 2014. № 1(1). P. 8-12.

DOI https://doi.org/10.30525/978-9934-588-81-5-2.46

\section{THE ROLE OF TELEMEDICINE DURING THE COVID-19 PANDEMIC}

\author{
Kiianytsia V. V. \\ Communications Specialist \\ State Institution «Public Health Center of the Ministry \\ of Health of Ukraine» \\ Kyiv, Ukraine
}

Introduction. As of the morning of September 24, 2020, 188106 cases of COVID-19 were laboratory confirmed in Ukraine and 3757 fatalities were registered. 